\title{
EFL Teachers' Conceptions of Professional Development during the Practicum: Retrospective Perceptions and Prospective Insights
}

\author{
Mozhgan Aghabarario[ and Mehrak Rahimi* (i)
}

\author{
* Correspondence: mehrakrahimi@ \\ yahoo.com; rahimi@sru.ac.ir \\ English Department, Faculty of \\ Humanities, Shahid Rajaee Teacher \\ Training University, Lavizan, Tehran \\ 1678815811, Iran
}

\begin{abstract}
The current study probes into English as a Foreign Language (EFL) teachers' conceptions of their professional development during practicum course. The study merits a mixed methods approach and has utilized both quantitative and qualitative data gathering and analysis. To gather quantitative data, $100 \mathrm{EFL}$ teachers were asked to complete a questionnaire that measured their retrospective perceptions of the role of practicum in their professional development. To gather qualitative data, 20 student-teachers (STs) of Teaching English as Foreign Language (TEFL) were asked to write narrations while they were taking part in their practicum courses for two years. The results of quantitative data analysis revealed that the participants had roughly positive retrospective perceptions of the practicum course and its role in their professional development. It was also found that novice teachers (with 1-5 years of experience), those participants whose practicum course lasted longer (two semesters or longer), and those who had taken part in the practicum after teacher education curriculum change had more positive perceptions of the practicum course. The result of qualitative analysis revealed that STs were generally satisfied with the content, methodology and assessment of the practicum. They reported certain challenges they faced during the practicum including relation with cooperating teachers and their supervisors' strictness. They also believed that the practicum helped them expand their pedagogical insights on EFL theories and practices, although they needed help on certain issues including assessment of students' learning.
\end{abstract}

Keywords: practicum, perceptions, EFL, teachers, professional development

\section{Introduction}

Education as a complex system consists of many interrelated components whose fullfledged functioning guarantees its success and the prosperity of the nation. Indisputably, teachers and their attributes such as personality, behavior, and teaching effectiveness are among the factors that have immense impacts on all other parts of the educational system directly and indirectly. Teacher education (TE) as a dynamic social

(c) The Author(s). 2020 Open Access This article is licensed under a Creative Commons Attribution 4.0 International License, which permits use, sharing, adaptation, distribution and reproduction in any medium or format, as long as you give appropriate credit to the original author(s) and the source, provide a link to the Creative Commons licence, and indicate if changes were made. The images or other third party material in this article are included in the article's Creative Commons licence, unless indicated otherwise in a credit line to the material. If material is not included in the article's Creative Commons licence and your intended use is not permitted by statutory regulation or exceeds the permitted use, you will need to obtain permission directly from the copyright holder. To view a copy of this licence, visit http://creativecommons.org/licenses/by/4.0/. 
activity is responsible for developing this multi-dimensional repertoire of teaching and familiarizing pre-service teachers with the future teaching context and its variables through collaboration with schools.

The collaboration between schools and TE program is often defined within the framework of a formal course called the practicum "in which pre-service teachers spend an extended time observing teachers, and preparing and delivering lessons under their supervision" (Walton \& Rusznyak, 2013, p. 113). Being a part of real teaching experience, transforming theoretical knowledge into practice, observing and learning from other teachers, developing lesson plans and teaching materials, and acquiring classroom management skills are among some of the opportunities practicum courses provide STs with (Crandall, 2000; Wright, 2010; Darling-Hammond, 2012). In addition, practicum courses would have a great influence on STs' attitudes towards and perceptions of teaching profession (Atay, 2007) and how they imagine themselves in the profession.

Integrating right type of practicum into TE programs demands fundamental shifts in theoretical bases and practical approaches of teacher education pedagogy. In this sense, educational reforms are inevitable and many countries have already considered the revision of their teacher training programs and the way universities and schools are linked through the practicum. Reviewing TE literature, however, shows that there is scarcity of research on the effectiveness of these changes on pre-service and in-service teachers' professional development. As a result, the current study tries to unveil EFL teachers' understanding of the role of practicum courses in their professional development by probing into their retrospective perceptions and prospective insights in a changed TE curriculum. The study would benefit from a mixed methods design to triangulate the findings of both quantitative and qualitative data gathering and analysis; and aims at answering the following research questions:

1. What are EFL teachers' retrospective perceptions of the role of practicum in their professional development?

2. Is there a significant difference between novice and experienced EFL teachers' retrospective perceptions of the role of practicum in their professional development?

3. Does the duration of practicum make a significant difference in EFL teachers' retrospective perceptions of the role of practicum in their professional development?

4. Does the type of practicum (before and after TE curriculum change) make a significant difference in EFL teachers' retrospective perceptions of the role of practicum in their professional development?

5. What are STs' conceptions and prospective insights of the experience of the practicum?

\section{Review of literature}

The issue of defining who qualified teachers are and how they are educated has been among the most critical questions posed in the literature of teacher education. It is widely accepted among policy makers to establish certain standards "to define what teachers should be able to do and what they should know" (Sachs, 2005, p. 582) to 
become effective teachers. Attending formal education that leads to teaching degrees/certificates is supposed to help teaching candidates meet these standards. This assumption is actually supported by empirical studies as teaching effectiveness and having a formal degree have been found to be related (Darling-Hammond, Holtzman, Gatlin, \& Heilig, 2005). TE is reported to equip teacher candidates with knowledge (Larsen-Freeman, 2000) and communication skills (Terenzini \& Reason, 2005) and impacts their emotions and self-efficacy (Hascher \& Hagenauer, 2016). Therefore, TE program has become the foundation of training effective teachers and "much of the perceived failure of schooling is attributed to teachers who are thought to be ill prepared for their task because teacher education is deficient" (Ben-Peretz, 2000, p. 48). As a result, many educational systems have invested heavily on improving the quality of TE programs to educate effective teachers and guarantee sustained development of the country. The quality of TE program, its underlying philosophy, and the type of courses STs attend affect the quality of teaching activities they incorporate into their future classes as the way STs are taught has a great impact on the way they teach (Cruickshank, Jenkins, \& Metacalf, 1995).

Preparing the ground for STs to become a member of teaching community within a given context and assisting them to develop their pedagogical content knowledge (PCK) have been suggested to be a kernel of TE programs. During formal education, teacher candidates should have the opportunity to attend schools to have a realistic portrayal of the profession and develop their teaching repertoire by doing the tasks the mentor and the supervisor ask them to do. The practicum familiarizes the prospective teachers with the milieu or "the educational context, including the array of cultural, social, racial, and other groups to which students and teachers belong" (Kanu, 2005, p. 495). In this process many teaching variables such as the quality of teaching, teaching behavior, competencies, and identity may take shape (Rahimi \& Nabilou, 2011).

The practicum is based on the notion of a "supportive journey of development and learning" (Keogh, Dole, \& Hudson, 2006, p. 3) where STs try to make a connection between theoretical concepts they learned in university and what takes place in school context. In this process, the cooperating teacher and the supervisor play pivotal roles in supporting STs to "interpret and analyze what they see and sense" (ibid). The practicum transforms a prospective teacher to a teacher and thus is a stressful experience for STs due to the gaps that exist between beliefs they developed during attending university courses and what is taking place at schools regardless of the formulated theories. "Student teachers bring their expanding, varying and at times conflicting understandings and knowledge to the practicum" (Ferrier-Kerr, 2009, p. 790) and very often need to spend so much energy and effort to resolve those issues. Differences that exist among STs such as their learning experience and cultural and linguistic differences (Cruickshank, Newell, Cole, 2003) can intervene the process implicitly or explicitly as well. Many STs believe that practicum is an extremely tedious job as they have to bear considerable pressure from the sides of the mentor and the supervisor and do their tasks in an appropriate way to fulfill the requirements of the course. A range of physical health complaints such as insomnia, intense fear, and eating disorders are even reported by those who experience practicum (Sandersoon, 2003, as cited in Campbell, Tangen, \& Spooner-Lane, 2006).

In spite of the difficulties reported in the literature, practicum is considered to be "a unique time in teachers' professional development" (Fives, Hamman, \& Olivares, 2007, 
p. 917) that leads to personal and professional growth and the development of more efficient teachers. Due to its importance, researchers have shown a surge of interest in scrutinizing the role of practicum in teacher development in recent years. Early studies on practicum have focused on the development of models and approaches of practicum and the advantages and disadvantages of their implementation. On a continuum of knowledge-for-practice (knowledge about teaching) to knowledge-in-practice (knowledge for teaching) three basic models of practicum can be located: the integrative, the partnership and the community of teachers model (Atputhasamy, 2005). In each model the role and strategic partnership for involved parties, i.e., STs, cooperating teacher, and teacher educators are defined and specified.

A line of empirical studies from a sociocultural perspective has also probed into the features of the practicum and their relevance to other components of the educational system. The role of school variables such as students' social and cultural differences (e.g., Partington, 1997), multigrade classes (e.g., Seban, 2015); implementing different practicum models (e.g., Becker, Waldis, \& Staub, 2019), relationship between STs and mentors (Smith, 2010), type of support provided in the practicum by cooperating teachers (Gurvitch \& Metzler, 2009), and challenges and barriers of school involvement for STs (Montecinos, Cortez, \& Walker, 2015) are among the factors studied in the literature in recent years. Some studies have also focused on the role of STs' individual differences in their perceptions of the practicum (Hascher \& Hagenauer, 2016); their attitudes towards the course (Ng, Nicholas, \& Williams, 2010); and the feeling (Chaplain, 2008) and beliefs (Yuan \& Lee, 2014) they have about the practicum.

Within this framework, a few studies have examined the practicum component of EFL teacher education. EFL STs' evaluation and dissatisfaction of the practicum program (Mirhassani \& Beh-Afarin, 2004), the effect of implementing reflective practicum (Maleki, 2017), critical needs analysis of the practicum (Masoumpanah, Tahririan, Afzali, \& Alibabaee, 2016), cognitions of STs and their possible changes through the practicum (Shooshtari, Razavipur, \& Takrimi, 2017), and the attitudes of pre-service EFL teachers towards the practicum (Can \& Baştürk, 2018) are among the investigated topics. There is, however, a gap in the literature regarding an in-depth analysis of the role of EFL teachers' perceptions of the practicum in their professional development and the way these perceptions shape their identity as an EFL teacher particularly by considering the changes that have taken place in recent years in the EFL teacher education programs. The current study aims at addressing this gap by utilizing a mixed methods design of research to probe into the perceptions of EFL teachers of their practicum course considering teaching experience, duration of the practicum, and the type of practicum. Further, STs' conceptions of the practicum course were analyzed through narrative inquiry of the stories produced in a 2-year period while they were taking part in the program.

\section{The context of the study}

In Iran, STs are admitted to teacher training programs based on their rank in the national university entrance exam and taking part in recruitment interviews. The undergraduate program normally lasts between 8 to 10 semesters during which the 
knowledge base of the STs takes shape. The practicum course is a compulsory component of TE program and STs are required to pass four semesters of practicum whose goal is providing them with pedagogical insights and professional skills. A short description of each practicum course would follow:

Semester 1: STs are asked to observe the classroom situation considering three factors:

- physical characteristics of the school including the school building and its size, school administrative structure, number of students, etc.

- students' emotional interaction with teachers and peers

- educational processes including teaching and learning behaviors

Semester 2: STs develop different types of instructional materials and activities. In fact, in this semester, STs can establish a link between the observations they did during the first practicum and the activities they design in the second semester.

Semester 3: STs focus on more practical aspects. They are required to attend the mentors' classes regularly and observe and formulate/orientate their professional qualities. They are expected to conduct their training activities in line with the "REACT" strategy (Relating, Experiencing, Applying, Cooperating, and Transferring).

Semester 4: STs should evaluate the EFL textbooks to become familiar with the instructional materials. They design a concept map to create a vision of what students are supposed to learn and they as teachers are expected to teach.

It should be noted that STs become familiar with the concept of narrative inquiry and how they have to organize their field notes into stories in in-class sessions of the practicum. In all training sessions they are required to write down the details of the events in a narrative and storytelling genre using their own language with reflections on all events. The techniques and procedure of data gathering, the required instruments, and the way the written reports should be prepared are specified in the syllabus of the course practicum (Karami, Seraji, \& Marufi, 2017) and both STs and teacher educators are required to follow them carefully.

\section{Method}

Participants

The participants of the study were 100 EFL certified teachers graduated from teacher training universities in Iran and all of them had degrees in Teaching English as a Foreign Language (TEFL).

The sample included both male and female teachers who ranged in age from 22 to 45. The participants were working in different educational contexts including public and private schools at the time of data gathering. A summary of the demographic information of the participants is presented in Table 1.

Further, to delve into STs' conceptions of the practicum course, 20 STs of TEFL who were taking part in their practicum course in years 2016-2018 were asked to write detailed narrations to gain an understanding of their personal and social experiences during attending the practicum. 
Table 1 Demographic information of the participants

\begin{tabular}{llll}
\hline Variables & & Female & Percent \\
Gender & Male & 61 & 61 \\
& $20-25$ & 39 & 39 \\
Age & $25-30$ & 34 & 34 \\
& $30-35$ & 30 & 30 \\
& $35-40$ & 13 & 13 \\
& $40-45$ & 15 & 15 \\
Teaching experience & $1-5$ & 8 & 8 \\
& $5-10$ & 38 & 38 \\
& $10-15$ & 18 & 18 \\
Duration of practicum & $15-$ above & 22 & 22 \\
Type of practicum & 2 semesters and less & 22 & 42 \\
Teaching context & More than 2 semesters & 49 & 51 \\
& Before change & 51 & 57 \\
& After change & 57 & 43 \\
& Public school & 43 & 52 \\
& Private school & 52 & 18 \\
& Both public and private schools & 30 & 30 \\
\hline
\end{tabular}

\section{Instruments}

To gather the quantitative data, the measure of 'perceptions of the role of practicum course in teachers' professional development' was used. The questionnaire was developed by the researchers after a careful review of the available literature, theoretical underpinnings related to the role of practicum in teachers' professional development (e.g., Wright, 2010; Darling-Hammond, 2012; Darling-Hammond, et al., 2005), and the role of practicum in TE programs of Iran (e.g., Ghanbari, Nikkhah, \& Nikbakht, 2018; Jamshiditavana, Imamjomeh, Assareh, \& Moosapour, 2017). First a pool of 20 items was created and then reviewed by three teacher educators. Based on the suggested changes, a 13-item questionnaire was finalized and its psychometric characteristics were checked (Table 2). The result of exploratory factor analysis (EFA) approved a four-dimension structure for the scale including:

(1) Improving in-class practice (5 items),

(2) Considering students' needs and variation of the context (4 items),

(3) Changing theory to practice (2 items), and

(4) The overall benefit of the practicum for teaching English (2 items).

The items were anchored on a five-point Likert scale from 1=strongly disagree to $5=$ strongly agree. The Cronbach's alpha reliability coefficient of the scale was found to be .71 .

To gather the qualitative data and to investigate STs' views and experiences regarding their professional development during their practicum courses, narrative inquiry was carried out. Narrative inquiry is a qualitative research method that lets the researchers "investigate the ways humans experience the world depicted 
Table 2 Summary of items and factor loadings from factor analysis

\begin{tabular}{|c|c|c|c|c|}
\hline \multirow[t]{2}{*}{ Items } & \multicolumn{4}{|c|}{ Factor loadings } \\
\hline & 1 & 2 & 3 & 4 \\
\hline \multicolumn{5}{|l|}{ 1. Improving in-class practice } \\
\hline $\begin{array}{l}\text { 1. The practicum helped me to present subjects/materials in ways } \\
\text { that build on students' existing understanding. }\end{array}$ & .851 & & & \\
\hline $\begin{array}{l}\text { 2. The practicum helped me to prepare my lesson plans by considering } \\
\text { visual, auditory and kinesthetic styles of students. }\end{array}$ & .717 & & & \\
\hline $\begin{array}{l}\text { 3. The practicum helped me to practice analyzing and reflecting on } \\
\text { the effectiveness of my teaching. }\end{array}$ & .781 & & & \\
\hline $\begin{array}{l}\text { 4. The practicum helped me to teach English in a meaningful context } \\
\text { and make language learning more enduring. }\end{array}$ & .705 & & & \\
\hline $\begin{array}{l}\text { 5. The practicum helped me to create a positive atmosphere in English } \\
\text { classes for students to motivate them towards learning English. }\end{array}$ & .777 & & & \\
\hline \multicolumn{5}{|l|}{ II. Considering students' needs and variation of the context } \\
\hline $\begin{array}{l}\text { 6. The practicum helped me to understand how to use alternative assessment } \\
\text { tools like portfolios, posters, quizzes, oral performance to evaluate students. }\end{array}$ & & .619 & & \\
\hline $\begin{array}{l}\text { 7. The practicum helped me to adapt my teaching practices to different high } \\
\text { school contexts in different neighborhoods. }\end{array}$ & & .555 & & \\
\hline $\begin{array}{l}\text { 8. The practicum helped me to use intercultural materials as well as the target } \\
\text { culture specific materials with students to raise their tolerance toward other } \\
\text { cultures. }\end{array}$ & & .338 & & \\
\hline $\begin{array}{l}\text { 9. The practicum helped me to set up activities that meet the learning needs } \\
\text { of students with diverse social, cultural, religious, and ethnic backgrounds. }\end{array}$ & & .399 & & \\
\hline \multicolumn{5}{|l|}{ III. Changing theory to practice } \\
\hline $\begin{array}{l}\text { 10. The practicum provided a link between theory and practice in the } \\
\text { classroom }\end{array}$ & & & .381 & \\
\hline $\begin{array}{l}\text { 11. The practicum provided an opportunity for me to reflect on my } \\
\text { professional knowledge }\end{array}$ & & & .580 & \\
\hline \multicolumn{5}{|l|}{ IIIV. Overall benefit of the practicum for teaching English } \\
\hline $\begin{array}{l}\text { 12. The practicum helped me to understand how to teach English in an } \\
\text { integrated manner. }\end{array}$ & & & & .853 \\
\hline $\begin{array}{l}\text { 13. The practicum experience prepared me for becoming a professional } \\
\text { EFL teacher. }\end{array}$ & & & & .523 \\
\hline Variance & 28.107 & 10.279 & 9.677 & 8.662 \\
\hline
\end{tabular}

through their stories" (Webster \& Mertova, 2007, p. 1). Details of the events and experiences the subjects under the study face and feel in their social contexts are reflected in narrative writing. "[J] ust as a story unfolds the complexities of characters, relationships and settings, so too can complex problems be explored in this way" (ibid, p. 4).

In this regard, daily narratives of 20 STs were analysed to investigate their views and experiences they gained regarding their professional development during their practicum courses.

\section{Data analysis}

In order to analyze the quantitative data, descriptive and inferential statistics including independent samples t-test and one-way analysis of variance (ANOVA) were used. In order to analyze the qualitative data, content analysis of the narrations was done. 


\section{Results}

\section{Quantitative data analysis}

To answer research question 1 and examine EFL teachers' retrospective perceptions of the role of practicum course in their professional development, descriptive statistics were used (Table 3).

As Table 3 shows, teachers had roughly positive perceptions of the role of the practicum in their professional development (mean $=2.971, \mathrm{SD}=.547$ ). Considering the components of the questionnaire, it was revealed that the highest value is related to factor 4, overall benefit of the practicum for teaching English (mean=3.38, SD=696). The lowest value, however, was related to factor 2 , teachers' perceptions of the role of practicum in making them aware of the milieu and its components (students, colleagues, and parents) (mean $=2.22, \mathrm{SD}=.471$ ).

To answer research question 2 and compare the participants' perceptions across teaching experience groups (1-5 years, 5-10, 10-15, above 15 years), ANOVA was run (Table 4).

As Table 4 shows, the result of ANOVA is significant $[\mathrm{F}(96,3)=16.888, p<.05]$ indicating that there is a significant difference between the considered groups. The result of Tukey post hoc test showed that novice teachers' perceptions were significantly more positive than other groups with a mean of 3.379 ( $\mathrm{SD}=.455$ ). Table 5 summarizes the descriptive statistics of the perceptions across groups of the participants with different teaching experience.

To answer research questions 3 and 4, and compare participants' perceptions considering the length of the practicum course they took part in $(2$ semesters and less vs. more than 2 semesters) and the time of passing the course (before and after TE curriculum change), independent-samples t-tests were used (Table 6).

As the result of t-test shows, there is a significant difference between the participants' perceptions considering the duration $[\mathrm{t}(98)=-6.498, p<.05)$ and type of the practicum [t $(98)=-19.178, p<.05)$. The results of the descriptive statistics (Table 7) show that those teachers whose practicum course was longer (mean $=3.264, \mathrm{SD}=.512$ ) and those who experienced the reformed practicum in recent years (mean $=3.529, \mathrm{SD}=.257$ ) had significantly more positive retrospective perceptions of the role of the practicum in their professional development.

\section{Qualitative data analysis}

Daily narrations written by 20 STs of TEFL during taking part in the practicum course for two years were qualitatively analyzed to delve into prospective teachers' conceptions of their professional development while attending the course. To analyze the narrations, the following steps were taken (Ezzy, 2002, as cited in Barusch, 2015):

Table 3 Descriptive statistics of the variables $(N=100)$

\begin{tabular}{lll}
\hline Variables & Mean & SD \\
Measure of perceptions & 2.971 & .547 \\
Factor 1. Improving in-class practice & 2.860 & .924 \\
Factor 2. Considering students' needs and variation of the context & 2.220 & .471 \\
Factor 3. Changing theory to practice & 2.860 & .728 \\
Factor 4. Overall benefit of the practicum for teaching English & 3.380 & .696 \\
\hline
\end{tabular}


Table 4 The result of ANOVA to compare participants' perceptions across teaching experience groups

\begin{tabular}{llllll}
\hline & Sum of Squares & df & Mean Square & $F$ & Sig. \\
Between Groups & 10.254 & 3 & 3.418 & 16.888 & $.000^{*}$ \\
Within Groups & 19.430 & 96 & .202 & & \\
Total & 29.684 & 99 & & & \\
\hline
\end{tabular}

1. The narrations were read and reread meticulously and necessary notes were taken while focusing on insights and understanding of each story

2. Stories were compared and contrasted for similarities and differences in content, style, and interpretation

3. Certain themes and subthemes emerged after careful analyses of the stories (Table 8)

4. The analyzed narrations were interpreted and the findings were discussed.

\section{General Conceptions}

General conceptions of STs emerged with respect to their attitudes towards the practicum (e.g., beliefs, feelings, worries), the content of the practicum (goals, activities, responsibilities), the supervisors' teaching methodology (e.g., strategies, approaches, expectations), and the assessment techniques. Further, the challenges and opportunities the STs faced during attending the practicum were identified.

\section{Attitudes}

Most STs had positive attitudes towards the practicum and found it useful to improve their teaching strategies, teaching practices, and classroom management skills.

I am very happy that I have participated in the practicum courses. I learned many strategies that were really effective for me in my classes; I learned how to manage my classes and how to plan my class activities.

The practicum helped those STs with certain presuppositions to develop positive attitudes and feelings towards the effectiveness of the course.

Before participating in practicum courses I supposed teaching could be something easy if you have all the required knowledge for teaching in that specific subject. But during this term I experienced that there are many other factors and skills that a teacher is required to know.

Honestly, this seemed something simple to me before experiencing a real situation of being a real teacher in a real classroom. Once I came into the class and I was

Table 5 Descriptive statistics

\begin{tabular}{llll}
\hline Groups based on teaching experience & N & Mean & SD \\
$1-5$ years & 38 & 3.379 & .455 \\
$5-10$ years & 18 & 2.745 & .365 \\
$10-15$ years & 22 & 2.678 & .429 \\
15 years-above & 22 & 2.746 & .517 \\
\hline
\end{tabular}


Table 6 The results of t-tests

\begin{tabular}{lllll}
\hline Comparisons & $\mathrm{t}$ & $\mathrm{df}$ & Sig. & Mean difference \\
Perceptions and the length of the practicum & -6.498 & 98 & $.000^{*}$ & -.598 \\
Perceptions and the type of practicum & -19.178 & 98 & $.000^{*}$ & -.977 \\
\hline
\end{tabular}

supposed to handle a class including at least 30 students with different demands and personalities, I wondered how I can manage this classroom! I don't know how to express my feelings; it was a sense of being worried and frightened.

\section{Planning of the course}

Content The content of the practicum made STs familiar with not only the pedagogical issues but also the administrative system and its procedures.

This term I found that although one day I was a student, there are many official rules about the school administrative structure that I hadn't been informed about and practicum made me familiar with all those official rules.

The content of the course made STs familiar with their future responsibilities and helped them shape their own identity as an EFL teacher.

In this term we were required to investigate our own observations in three steps: Describe, review, determine the focal point and explain the problem. In fact these observations made us familiar with what and how we are supposed to teach in the future.

Today we were required to attend the class and observe teacher's nonverbal communication and through this formulate or orientate her professional qualities.

Further, it seems that the activities have improved STs' self-efficacy and the way they imagine themselves in the job.

I have to describe my features as a teacher, the position I teach, and the expression of goals and ideals in the form of a narration.

I realized that writing about my own experience of teaching can give me a great insight of my teaching process and also made me reflect on my teaching, my behavior as a teacher, my feelings, etc.

Table 7 Descriptive statistics

\begin{tabular}{lllll}
\hline Variables & Groups & $\mathrm{N}$ & Mean & SD \\
Duration of the practicum & 2 semesters and less & 49 & 2.666 & .397 \\
& More than 2 semesters & 51 & 3.264 & .512 \\
Type of practicum & Before TE change & 57 & 2.551 & .248 \\
& Changed TE curriculum & 43 & 3.529 & .257 \\
\hline
\end{tabular}


Table 8 The coding scheme of STs' conceptions of professional development during practicum

\begin{tabular}{lll}
\hline Codes & Themes & Subthemes \\
General conceptions & Attitudes & Beliefs, emotions, intended behavior \\
& Planning of the course & Content (goals, activities, responsibilities) \\
& & Methodology \\
& Assessment \\
Implementation & Challenges (problems/limitations) \\
Professional development & Pedagogical insights & Teaching techniques/tactics \\
& The milieu & Students, teachers, school \\
\hline
\end{tabular}

STs believed that their needs as prospective teachers are well addressed in planning the content and activities of the practicum like writing a lesson plan, creating different activities based on students' needs, providing interesting games related to the topic of their lessons, deploying useful strategies (e.g. REACT strategies), etc.

Fortunately, in this term I practiced the skills that were really effective for me as a teacher, like writing a lesson plan, creating different tasks based on my students' needs, learning useful strategies and so on. All these processes were well-organized and taught gradually and made us perfect in these skills.

Honestly, learning how to design a unique activity for your class and also learning how to create activities to manage the problems you may encounter in your class regarding the matters like students' homework and eliminating academic retardation showed that the content covered had a logical order.

Methodology The teacher educator used a variety of teaching techniques to help STs develop professionally. These techniques were basically inductive, asking students to observe explicit behaviors and then come up with general rules and patterns.

From the examples she provided, I learned that my intonation in giving feedback to my students is really important and can have two controversial effects: making students eager to continue learning or making them completely frustrated.

Teacher educators were also attentive to the ways STs should improve their selfefficacy and be fair about their weaknesses and strengths.

This term our supervisor made us express our own characteristics as a teacher. We were required to write our own characteristics with detailed explanation. 
Supervisors used Information and Communication Technologies (ICTs) in their own teaching and gave orientation to STs to take advantage of available technologies to prepare their tasks as well.

My supervisor in the practicum course insists on using technology for creating our activities in the class.

Teacher educators made an effective link between theories taught in the university and practices required at the school level.

On Mondays we had a class with our supervisor and she taught us some theories about teaching, moreover she defined what we were required to do at school on Wednesdays.

Some STs thought that the activities they were required to do were really demanding and time consuming, although valuable.

Today I am writing my sixth narrative of my teaching practice, I should really thank her for her demanding and very helpful projects.

To be honest with myself, at the beginning sessions of my practicum course, I was always nagging about the demanding works that she always asked us to do.

Assessment The way STs were assessed was one major theme in their narrations. One of the beneficial assessment techniques mentioned is reflection via diary writing, narrations, and watching recorded sample teachings.

Today I was reading my narratives and I could see the progress of my teaching only because of those reflections that I myself had about my teaching practice.

I think I have developed a lot in comparison to my first teaching practice. No one could criticize me for my mistakes and behaviors except myself. So I would keep on writing my diaries as my narratives in the future.

\section{Implementation (opportunities and challenges)}

STs believed that practicum has been a great opportunity to become familiar with different aspects of the educational system they were ignorant or inattentive to, such as students' needs and differences, curriculum change, and self-assessment of their professional development.

Hopefully, we were required to work on the new version of student books covered at schools and also provide other materials such as videos, songs and games related to the themes covered in the book to teach more effectively. 
I've got familiar with different methods of assessing students such as providing something like a portfolio of students' works to analyze their progress during the term.

Like any other program, there were certain challenges STs reported to face during their practicum. These challenges included the demanding nature of designing different types of activities, heavy responsibilities they had, supervisors' strict characteristics, unpredictable issues raised in real classes, and relationship with cooperating teachers.

Performing all the things she [the supervisor] wanted me to do was really demanding and time consuming. It requires a lot of hard work to perform whatever she said.

During the process of designing the worksheet, my supervisor asked me to change my activities four times! She was a very austere woman. She didn't tolerate even the tiny mistakes. She wanted us to do our works perfectly from the first session.

There were some unexpected incidents that challenged STs, although these issues are quite normal for a school setting.

Today, I faced an unexpected situation, like before, we had prepared a lot of programs and designed lesson plans to teach in the class. But unfortunately, due to the late arrival of the students in the class, as well as exposure to conditions that we hadn't anticipated before, I could not run all my plans at this session.

They had some issues with cooperating teachers as they did not welcome STs' presence in their classes.

Some teachers at schools were not satisfied with the attendance of pre-service teachers in their classes. They didn't let us attend their classes. Finding an eager teacher to accept us in her class took a lot of time from us.

Lack of background knowledge on certain topics and generation gap seemed to be another challenge STs faced during their attendance in real classes.

In my students' writings I surprisingly faced some new, fashionable and strange things regarding different subjects such as different styles in music, different famous actors that I even didn't know! To be honest I was shocked at first, maybe that was my mistake that I wasn't informed enough about the interests of my young students and I felt I really need to be UPDATED.

One of the most serious challenges STs faced was how to assess students' achievement.

In fact, to me assessing is the most difficult part of the teaching process but unfortunately we couldn't fulfil these ways of assessing in our teaching practices because of 
the shortage of time. I don't know ... maybe I should study more about assessment and testing.

Professional development

Teachers' ideas about their professional development with regard to how the practicum improved their pedagogical insights and their understanding of the milieu and its variables were also recognized in their narrations.

\section{Pedagogical insights}

In the process of the practicum STs realized the value of using supplementary materials in their classes.

I tried and search[ed] many hours to find a suitable video about 'health' to show in the class and I could really see the effects of acts in the video that made even the laziest student in the class to watch the video carefully and find the answers of the activities they were required to do. Experiencing such energetic class was really amazing for me!

They also became aware of the importance and value of certain teaching techniques and activities during being a part of a real class including having a well-defined lesson plan, some guidelines for designing worksheets and class activities and the effects of teachers' body language in teaching.

Using new strategies was very useful and also practical for creating an enjoyable atmosphere in my classes. It also enables me to teach the new materials in a strategic way which makes learning more effective. When I used this strategy in my today's teaching practice, I felt that students learned what I intended to teach step by step in a meaningful way. Now I am very happy that I learned this strategy, although it is a little time consuming but its results are wonderful.

I understood that sometimes in some of the group form activities only one student takes on the responsibilities assigned and the rest of the students will not take part actively in the assigned activity. So I came into the conclusion that the combination of classroom activities in both group and individual form could lead to a better and deeper learning.

I realized that the most important thing is having a lesson plan for every minutes and even every seconds that I as a teacher have in the classroom. I found out that those teachers who have an exact and effective lesson plan are more successful than those who do not.

I understood that designing worksheets and class activities in the form of both individual and group work provides this opportunity for all students to participate in class activities and prevents any kind of buck passing from some lazy students. 


\section{The milieu}

STs referred to the value of practicum in familiarizing them with the teaching context and its variables including students, colleagues, school environment, and teaching materials.

Students played an important role in STs' teaching practice. They realized that students' characteristics and their individual differences can be sources of variation in teaching and learning.

Considering psychological factors regarding the age of my students which were between 13-15 years old, I tried to use some games instead of teaching in a traditional way. I realized that in this way students became more eager to do the games and simultaneously learned the lesson more effectively.

I can say that I really ignored the power of the students' creative mind. Today when I designed a new activity for my students and put them in a new situation that they had never experienced before, unexpectedly I encountered a new version of my students with their beautiful writings which were full of creativity and also imaginary sentences and I realized that selecting new subjects and engaging students with new topics can stimulate their creativity and also their enthusiasm in doing the activities and eventually leads to very interesting writings of the students.

I understood that my students are really sensitive to my words and behaviour and it was very effective in making my students eager or disappointed toward learning English.

Teachers and their relation with each other and the way they cooperate with the administration at school were another important component of the environment.

I realized that the interactions and also the relationships between teaching staff and teachers together could be really effective in creating a peaceful and friendly atmosphere which leads to a great success in reaching all educational goals. Fortunately, I have experienced both of these teaching environments, the one in which there were low sense of cooperation and friendship between school staff and also the one in which everyone seemed to be friendly with each other and the whole team at school tried to create a peaceful atmosphere. In fact in the second one the dominant atmosphere was full of hopefulness and pleasure which led to success in all parts of the educational system.

The school environment and its type were realized to be among the factors that can affect professional development.

During this term I experienced teaching in 2 different schools in 2 different parts of the city; one in uptown and the other near downtown. Definitely I can say my students were totally different from each other. Today when I performed my lesson 
plans in the class which was at the school near downtown, I realized that although my students are at the same age, they are really different from each other. Their interests, their behavior toward their teacher, their demands, their proficiency level, their culture, ... . were totally different from my students in uptown.

STs had the chance of becoming familiar with the curriculum change when they attended the school. One component of that was newly designed EFL textbooks.

By drawing concept map of the new textbooks we got a general understanding of what the textbook emphasizes, as well as what the students would face during the academic term.

\section{Discussion}

The key goal of this study was probing into EFL teachers' conceptions of their professional development during the practicum. The study utilized a mixed methods approach and analyzed both retrospective perceptions and prospective insights of preservice and in-service teachers of English as a Foreign Language.

The results of the study primarily revealed that EFL teachers have roughly positive retrospective perceptions of the role of practicum in their professional development. But when groups of teachers were compared, it was revealed that these perceptions are relevant to teaching experience, duration of the practicum, and the type of practicum they took part in. This implies that TE change has been successful to some extend as those teachers who have taken part in practicum courses recently and experienced longer practicum designed based on pedagogically sound theories and practices have more positive perceptions of the practicum. The finding is in disagreement with that of Ronfeldt and Reiniger (2012) indicating that the extended length of the practicum improves the quality of the course, as when time is sufficient for observation and experience during the practicum, STs are exposed to a variety of activities and tasks they are required to do in the future as teachers (McNamara, 1992). On the other hand, short practicum courses would influence STs' sense of professional development in a negative way and send them into class unprepared and stressed out. Limiting the time and shrinking the syllabus of the practicum would make novice teachers be in constant search of information to address their problems in the very first few years of their teaching, while most of these issues could have been resolved during the practicum.

The results of qualitative data analysis revealed that the practicum has created and developed positive attitudes towards teaching strategies, teaching practices and classroom management skills. Although at the beginning negative emotions existed towards the supervisor and the tasks, STs' attitudes turned into positive gradually by understanding the values of the tasks. These positive attitudes brought about positive motivation and force to do the tasks more willingly by the passage of time and appropriate support of the supervisor. The finding corroborates theoretical and practical underpinnings related to the construct 'attitude' and its emotional, cognitive, and behavioral components (Liaw, 2002). When the emotions involved are controlled and managed by external variables appropriately (such as previous experiences) positive perceptions and beliefs take shape and thus the attitudes find a great chance to be transformed into behavior and satisfactory performance. Very related to this finding is the fact that the 
activities of the practicum improved STs' sense of identity and self-efficacy and thus made them feel quite ready to embrace the teaching position in spite of all demerits reported for the profession such as low salary, high responsibility, and crowded classes (Pourshahbaz, 2016). The real picture of the job would guarantee teachers' remaining in the job and may help them plan and execute their administrative and academic works more efficiently and thus not to suffer from job burnout.

The content of the practicum made STs familiar with educational issues and administrative procedures (e.g., educational rules and regularities) and appropriate use of technology and thus has suitably targeted the development of Technological and Pedagogical Content Knowledge (TPACK) of EFL teachers. This knowledge base prepares the prospective teachers for the classes of the 21st century as students of this generation are accustomed to using technological devices quite frequently for different reasons. If teachers cannot use technologies appropriately in their classes, the students would get bored, demotivated and inattentive during class time. This would ultimately create classroom management and disciplining problems. It should be noted that ICT use was limited to very simple literacies such as tape-recording sample teachings and writing them on DVDs, and searching the Internet for finding supplementary instructional materials. It seems that the systematic development of technological knowledge base of the STs is still in need of further attention.

During the practicum, STs encountered an insightful analysis of the needs of the learners. This insight enables STs to make appropriate instructional decisions and tailor their teaching styles to the needs of their students. This negotiated syllabus gives "high priority to the recognition of learner needs within a course and to the need to continually adjust courses while they are running to suit changing needs and circumstances" (Nation \& Mcalister, 2010, p. 149). They also gained awareness towards the curriculum change of the Iranian mainstream education and its components including what they have to teach, how they have to deliver instruction, and how they are supposed to assess students' achievement. As a consequence, they would develop positive attitudes towards change, understand reasons and dimensions of change, and ultimately accept it, as "introducing change to teachers .... means addressing teacher beliefs" (ibid, p. 176). This supports previous research that the practicum courses "provide first hand encounters with the realities of life in schools and classrooms from a teacher's perspective" (Borg, 2006, pp.276-277). One negative issue STs faced during their presence at school was that the mentors did not cooperate with them as it was expected. Inappropriate behavior of cooperating teachers towards STs is reported in the literature (Masoumpanah et al., 2016). As there is no systematic training for cooperating teachers in TE program of Iran and they are not well paid for this extra duty, they are often not willing to be a part of the practicum program as they think this is just another burden on their shoulders. Considering the mentors' key role in the success of the practicum, this critical issue should be addressed by administrators and teacher educators more seriously.

\section{Conclusions}

The findings of this study revealed that EFL teacher education change has been successful to some extend as some factors including teaching experience, duration of the practicum, and the type of practicum had some relations with more positive retrospective perceptions of the practicum. Further, STs were generally satisfied with the content, 
methodology and assessment components of the practicum and the practicum could raise STs' awareness towards the large-scale curriculum change and creating positive attitudes towards teaching strategies, instructional practices and classroom management skills.

Also, taking part in practicum was found to be effective in expanding STs' prospective pedagogical insights of EFL theories and practices and made them familiar with educational issues, administrative procedures, and learners' needs. Yet, the practicum course requires some amendments in certain issues including assessment of students' achievement and training of cooperating teachers.

\section{Abbreviations}

ANOVA: Analysis of Variance; CK: content knowledge; EFL: English as a Foreign Language; ICT: Information and Communication Technology; PCK: pedagogical content knowledge; PK: pedagogical knowledge; REACT: Relating, Experiencing, Applying, Cooperating, Transferring; ST: student teachers; TE: teacher education; TEFL: Teaching English as a Foreign Language; TPACK: Technological and Pedagogical Content Knowledge; TK: technological knowledge

\section{Acknowledgements}

The authors express their sincere appreciation to the reviewers for their constructive comments and insightful suggestions.

\section{Authors' contributions}

Dr. Rahimi guided the whole project. Ms Aghabarari gathered the data. Both authors are responsible for data analysis, interpreting the data, and producing the manuscript. The author(s) read and approved the final manuscript.

\section{Funding}

No grant or fund has been received by the authors.

\section{Availability of data and materials}

Since mixed methods approach was used in this study, most parts of the data are shared with the readers in the Manuscript.

\section{Competing interests}

There is no competing interest.

Received: 15 August 2019 Accepted: 27 March 2020

Published online: 21 April 2020

\section{References}

Atay, D. (2007). Beginning teacher efficacy and the practicum in an EFL context. Teacher Development, 11(2), $203-219$.

Atputhasamy, L. (2005). Cooperating teachers as school based teacher educators: Student teachers' expectations. Australian Journal of Teacher Education, 30(2), 1.

Barusch, A. (2015). Retrieved from http://amandabarusch.com/tools-for-narrative-research/step-by-step-approach-to-narrativeanalysis/

Becker, E. S., Waldis, M., \& Staub, F. C. (2019). Advancing student teachers' learning in the teaching practicum through Content-Focused Coaching: A field experiment. Teaching \& Teacher Education, 83, 12-26.

Ben-Peretz, M. (2000). When teaching changes, can teacher education be far behind? Prospects, 30(2), $215-224$.

Borg, S. (2006). The distinctive characteristics of foreign language teachers. Language Teaching Research, 10(1), 3-31.

Campbell, M. A., Tangen, D., \& Spooner-Lane, R. S. (2006). A program for preparing ethnic minority student teachers for practicum. International Journal of Practical Experiences in Professional Education, 9(2), 1-10.

Can, D. T., \& Baştürk, M. (2018). Qualitative research: The pre-service EFL teachers' opinions on teaching practicum. Trakya University. Journal of Social Science, 20(1), 187-212.

Chaplain, R. P. (2008). Stress and psychological distress among trainee secondary teachers in England. Educational Psychology, 28(2), 195-209.

Crandall, J. J. (2000). Language teacher education. Annual Review of Applied Linguistics, 20, 34-55.

Cruickshank, D. R., Jenkins, D. B., \& Metcalf, K. K. (1995). The act of teaching. New York: McGraw-Hill.

Cruickshank, K. E. N., Newell, S., \& Cole, S. (2003). Meeting English language needs in teacher education: A flexible support model for non-English speaking background students. Asia-Pacific Journal of Teacher Education, 31(3), 239-247.

Darling-Hammond, L. (2012). Powerful teacher education.: Lessons from exemplary programs. US: John Wiley \& Sons.

Darling-Hammond, L., Holtzman, D. J., Gatlin, S. J., \& Heilig, J. V. (2005). Does teacher preparation matter? Evidence about teacher certification, teach for America, and teacher effectiveness. Education Policy Analysis Archives/Archivos Analíticos de Políticas Educativas, 13, 1-48.

Ferrier-Kerr, J. (2009). Establishing professional relationships in practicum settings. Teaching \& Teacher Education, 25, $790-797$.

Fives, H., Hamman, D., \& Olivarez, A. (2007). Does burnout begin with students teaching? Analyzing efficacy, burnout, and support during the student-teaching semester. Teaching \& Teacher Education, 23(6), 916-934.

Ghanbari, M., Nikkhah, M., \& Nikbakht, B. (2018). The pathology of Farhangian University internship: A mixed study. Journal of Theory \& Practice in Curriculum, 10(5), 33-64. 
Gurvitch, R., \& Metzler, M. W. (2009). The effects of laboratory-based and field-based practicum experience on pre-service teachers' self-efficacy. Teaching \& Teacher Education, 25(3), 437-443.

Hascher, T., \& Hagenauer, G. (2016). Openness to theory and its importance for pre-service teachers' self-efficacy, emotions, and classroom behavior in the teaching practicum. International Journal of Educational Research, 77, 15-25.

Jamshiditavana, A., Imamjomeh, M. R., Assareh, A., \& Moosapour, M. (2017). Examining Farhangian University STs' experiences of the practicum. Journal of Training and Learning Research, 14(2), 67-77.

Kanu, Y. (2005). Teachers' perceptions of the integration of Aboriginal culture into the high school curriculum. Alberta Journal of Educational Research, 51(1), 50-68.

Karami, Z., Seraji, F., \& Marufi, Y. (2017). A narrative inquiry curriculum and professional development of student-teachers in Farhangian University: Design curriculum model. Journal of Theory \& Practice in Curriculum, 9(5), 69-104.

Keogh, J., Dole, S., \& Hudson, E. (2006). Supervisor or mentor? Questioning the quality of pre-service teacher practicum experiences. Adelaide, Australia: Paper presented at the AARE Annual Conference.

Larsen-Freeman, D. (2000). Techniques and principles in language teaching. Oxford: Oxford University.

Liaw, S. (2002). An Internet survey for perceptions of computers and the World Wide Web: Relationship, prediction, and difference. Computers in Human Behavior, 18, 17-35.

Maleki, M. (2017). On the impact of an EFL reflective practicum on teachers' self-efficacy. Journal of Applied Linguistics and Language Research, 4(4), 161-174

Masoumpanah, Z., Tahririan, M. H., \& Afzali, K. (2016). A critical needs analysis of practicum courses at Farhangian University: Mentors and students' perspectives. Iranian Journal of English for Academic Purposes, 5(2), 42-60.

McNamara, D. (1992). The reform of teacher education in England and Wales: Teacher competence; panacea or rhetoric? Journal of Education for Teaching, 18(3), 273-285.

Mirhassani, A., \& Beh-Afarin, R. (2004). Assessment of needs, pedagogical constraints and objective setting in EFL teacher education programs (TEPs): EFL Teacher Education Evaluation. Roshd FLT Journal, 69(16), 45-57.

Montecinos, C., Cortez, M., \& Walker, H. (2015). School administrators' understandings and management of barriers for the school's involvement in the practicum component of initial teacher education in Chile. International Journal of Educational Development, 43, 100-108.

Nation, I. S. P., \& Mcalister, J. (2010). Language curriculum design. NY: Routledge, Taylor and Francis Group.

$\mathrm{Ng}$, W., Nicholas, H., \& Williams, A. (2010). School experience influences on pre-service teachers' evolving beliefs about effective teaching. Teaching \& Teacher education, 26(2), 278-289.

Partington, G. (1997). Practice teaching in remote Aboriginal communities: The need for adaptation to the social and cultural context. Australian Journal of Teacher Education, 22(1), 5.

Pourshahbaz, S. (2016). The role of ICT use in language teaching and EFL teachers' job burnout as mediated by their TPACK (Unpublished master's thesis). Tehran: SRTTU.

Rahimi, M., \& Nabilou, Z. (2011). Iranian EFL teachers' effectiveness of instructional behavior in public and private high schools. Asia Pacific Education Review, 12(1), 67-78.

Ronfeldt, M., \& Reininger, M. (2012). More or better student teaching? Teaching \& Teacher Education, 28(8), 1091-1106.

Sachs, J. (2005). Teacher education and the development of professional identity: Learning to be a teacher. In P. M. Denicolo \& M. Kompf (Eds.), Connecting policy and practice: Challenges for teaching and learning in schools and universities (pp. 5-21). London: Routledge, Taylor and Francis Group.

Seban, D. (2015). Development of preservice identities: learning from a multigrade classroom practicum context. Journal of Education for Teaching, 41(1), 19-36.

Shooshtari, Z., Razavipur, K., \& Takrimi, A. (2017). Pre-service language teachers' cognitions about language learning/teaching and cognition refinements through a reflection-oriented practicum. Iranian Journal of Applied Linguistics, 20(1), 185-217.

Smith, K. (2010). Assessing the Practicum in teacher education-Do we want candidates and mentors to agree? Studies in Educational Evaluation, 36(1-2), 36-41.

Terenzini, P. T., \& Reason, R. D. (2005). Parsing the first year of college: A conceptual framework for studying college impacts. Paper presented in Annual Meeting of the Association for the Study of Higher Education, Philadelphia, PA.

Walton, E., \& Rusznyak, L. (2013). Pre-service teachers' pedagogical learning during practicum placements in special schools. Teaching \& Teacher Education, 36, 112-120.

Webster, L., \& Mertova, P. (2007). Using narrative inquiry as a research method: An introduction to using critical event narrative analysis in research on learning and teaching. London: Routledge, Taylor and Francis Group.

Wright, T. (2010). Second language teacher education: Review of recent research on practice. Language Teaching, 43(3), 259-296.

Yuan, R., \& Lee, I. (2014). Pre-service teachers' changing beliefs in the teaching practicum: Three cases in an EFL context. System, 44, 1-12.

\section{Publisher's Note}

Springer Nature remains neutral with regard to jurisdictional claims in published maps and institutional affiliations. 